\title{
The Biunik of Isotonic Safety with the Addition of Arabic Gum
}

\author{
Thresia Dewi K.B. ${ }^{1}$, Sitti Sahariah R. ${ }^{1}$, Sirajuddin ${ }^{1}$ \\ ${ }^{1}$ Associate Professor, Department Nutrition and Dietetic, Health Polytechnic of Makassar, Makassar, Indonesia, \\ ${ }^{2}$ Associate Professor, Department Dietitian profession, Health Polytechnic of Makassar, Makassar, Indonesia
}

\begin{abstract}
Background: Endurance sports greatly affect fluid requirements. The exercise that is too heavy will cause a lot of body fluids to come out. Providing sports drinks with carbohydrate and electrolyte content has more benefits for athletes. One of them is an isotonic drink formula with the addition of gum Arabic. The food safety factor in isotonic drink formulas is very important to prevent side effects due to the contamination of food or beverages that can endanger health.
\end{abstract}

Objectives to determine the food safety of the isotonic drink formula with the addition of gum Arabic.

Method: This study is the pre-experimental. Food safety, which includes microbial and metal contaminants, was analyzed at the Makassar Health Laboratory Center. The results showed that the isotonic beverage formula with the addition of gum Arabic was safe from metal contamination.

Results of the microbial contamination test shows that Biunik (F1) is an isotonic drink formula with the addition of safe Arabic gum, while other formulas still exceed the quality requirements of isotonic drinks in Indonesia based on ISN 01-4452-1998.

Keywords: Gum Arabic, Food Safety, Isotonic Beverage Formula.

\section{Introduction}

Performance in sports is the main objective of a competition. Maximum achievement can be obtained if the athlete is in good nutrition. Exercise requires energy that is obtained from nutrients in the food or drinks consumed. So achievement and energy are inseparable. Nutritional needs for adolescent athletes are relatively greater in nutritional needs, because adolescents still experience a period of physical growth and development of very fast behaviors such as lifestyle, eating habits, eating behavior disorders, physical activity, and the frequency and duration of exercise ${ }^{(1),(2)}$

\section{Corresponding Author: \\ Sirajuddin}

Associate Professor, Department Nutrition and Dietetic, Health Polytechnic of Makassar, Makassar, Indonesia

Address: Street Paccerakkang No.14, Biringkanaya, Makassar City, South Sulawesi, Indonesia-90241

e-mail: sirajuddin.gizi@poltekkes-mks.ac.id
Endurance sports greatly affect fluid requirements. The exercise that is too heavy will cause a lot of body fluids to come out. Nearly $70 \%$ of the human body consists of fluids. Although it does not contain energy, it is very important to improve sports performance and is needed to help the body's metabolism to produce energy. The intake of fluids in an athlete's body needs to be balanced by drinking drinks containing electrolytes ${ }^{(3) .(4)}$ gut microbiota have been studied extensively for health promotion, disease prevention, disease treatment, and exercise performance. It is recommended that athletes avoid dietary fiber and resistant starch to promote gastric emptying and reduce gastrointestinal distress during exercise, but this diet may reduce microbial diversity and compromise the health of the athlete's gut microbiota. Objective: This study compared fecal microbiota characteristics using high-throughput sequencing among healthy sedentary men (as controls, ${ }^{(5)}$

Giving fluids to athletes is a form of prevention of dehydration and maintaining body fluid balance. Dehydration means the lack of fluids in the body because the amount that comes out is greater than the amount 
that is entered. Dehydration can result in hyponatremia, hypoglycemia, hypokalemia so that athletes feel nauseous, dizzy, tired, and reduce the concentration (performance) of athletes during training or competitions. Sports drinks containing carbohydrates and electrolytes have even more benefits. In addition to providing a sweet taste, carbohydrates such as glucose, sucrose, and fructose are also useful for increasing energy, preventing hypoglycemia (decreased blood glucose), preventing weakness, and reducing stress hormone levels in the body. While the electrolyte content in it such as sodium, potassium, and chloride can prevent muscle cramps. ${ }^{(6)}$

Food safety is a condition and an effort needed to prevent the possibility of contamination of biological, chemical, and other objects that can disturb, harm, and endanger human health. One aspect of food safety is carried out through food sanitation as an effort to create and maintain food conditions that are healthy, hygienic, and free from the danger of contamination. The food safety factor is very important for a food product, both food and beverage to prevent side effects due to food contamination that can endanger health. ${ }^{(7)}$

Security dap is defined as a state free from the danger of injury or damage to the wearer. If the security aspect is not considered, then food or drink can turn into a source of disaster, a source of disease and death. There are three important things that can cause contamination in food and beverages. The first is handling food ingredients that do not comply with hygiene requirements. Second, in the processing process and the use of processing equipment and unclean presentation. Finally, when the food or drink is left idle or stored for too long at an inappropriate temperature. ${ }^{(8)}$

The number of isotonic beverage products on the market has attracted researchers to determine the safety of isotonic drink formulas that use local food ingredients, namely purple sweet potatoes. This isotonic drink formula is a development of Justin's research results (2019), to produce a sports drink formula based on purple sweet potato, there is still starch deposits in the resulting drink, so the addition of a stabilizer is required in the manufacturing process. One of the stabilizers that meet these requirements is gum Arabic. This study aims to determine the food safety of the isotonic drink formula with the addition of gum Arabic. Food safety in question is metal contamination and microbial contamination. ${ }^{(9)}$

\section{Material and Method}

This research is pre-experiment with a completely randomized design (CRD) that there are three treatment addition of gum Arabic, which is $0.1 \%, 0.2 \%$, and $0.3 \%$ in the isotonic drink made from 75 grams of purple sweet potato. This research was conducted at the Food Technology Laboratory the Health Polytechnic of Makassar in February-September 2020. The materials used to make samples of isotonic drink formulas are purple sweet potato, sweet orange juice, sugar, table salt $(\mathrm{NaCl})$, water, and gum Arabic. The tools used are a blender, cutting board, knife, sieve, scale, basin, gas stove, pan, squeezer, hand gloves, measuring cup, spoon, covered container, sample glass..Prepare all the ingredients and tools needed in the manufacture of an isotonic drink formula. The purple sweet potato is cleaned, then steamed for \pm 30 minutes, skinned, and weighed as much as 75 grams for each formula. After the blend by adding $\mathrm{m}$ strangers each $250 \mathrm{ml}$ mineral water. Sweet potato filtrate was filtered to obtain purple sweet potato juice. The purple sweet potato juice is heated for 1 minute, then cooled. After that, add $25 \mathrm{ml}$ of sweet orange juice, sugar, table salt, and gum arabic. Stir until smooth, using a boxed bottle of plastic and glass bottles.

Findings: The safety of isotonic drink formulas is tested from metal contaminants and microbial contaminants to comply with SNI 01-4452-1998 regarding the quality of isotonic drinks. The metal contamination of the isotonic drink formula with the addition of gum Arabic which is done twice for each formula.

Metal Contamination: The result of metal contamination analysis using the atomization method in the isotonic drink formula with the addition of gum Arabic showed that the average results were below the ISN for isotonic drinks, namely for arsenic metal a maximum of $0.1 \mathrm{mg} / \mathrm{kg}$, maximum mercury $0.03 \mathrm{mg} / \mathrm{kg}$, maximum zinc $5.0 \mathrm{mg} / \mathrm{kg}$, stannum maximum $40 \mathrm{mg}$ / $\mathrm{kg}$, maximum copper $2.0 \mathrm{mg} / \mathrm{kg}$ and maximum lead 0.3 $\mathrm{mg} / \mathrm{kg}$.

Microbial Contamination: The results of the Total Plate Count (TPC) of bacteria in the isotonic drink formula with the addition of gum Arabic showed that the TPC of bacteria for all formulas decreased from the results of the I test. The results of the TPC analysis for mold/yeast showed that the second TPC of mold/yeast 
in the isotonic drink formula decreased the TPC of mold/yeast for the formula. F1 and F3. The increase in mold/yeast TPC was seen in the F0 and F2 formulas in examination II. While the results of the Salmonella $\mathrm{Sp}$ examination showed that no Salmonella Sp content was found in the isotonic drink formula with the addition of gum Arabic.

Table 01. Results of Metal Contamination and Microbial Contamination Analysis are appropriate SNI 01-4452-1998 Isotonic Drinks

\begin{tabular}{|c|c|c|c|c|c|c|c|}
\hline \multirow{2}{*}{ No. } & \multirow{2}{*}{ Type of Test } & \multicolumn{4}{|c|}{ Levels } & \multirow{2}{*}{ Unit } & \multirow{2}{*}{ Requirements* } \\
\hline & & F0 & F1 & $\mathbf{F 2}$ & F3 & & \\
\hline \multirow[t]{6}{*}{1} & Metal contamination & & & & & & \\
\hline & Lead $(\mathrm{Pb})$ & $<0.01$ & $<0.01$ & 0.05 & $<0.01$ & $\mathrm{mg} / \mathrm{kg}$ & $\max .0 .3$ \\
\hline & Copper $(\mathrm{Cu})$ & 0.34 & 0.24 & 0.21 & 0.23 & $\mathrm{mg} / \mathrm{kg}$ & $\max .2 .0$ \\
\hline & Zinc $(\mathrm{Zn})$ & 0.35 & 1.11 & 0.20 & 0.22 & $\mathrm{mg} / \mathrm{kg}$ & $\max .5 .0$ \\
\hline & Mercury (Hg) & $<0.0005$ & $<0.0005$ & $<0.0005$ & $<0.0005$ & $\mathrm{mg} / \mathrm{kg}$ & $\max .0 .03$ \\
\hline & Tin $(\mathrm{Sn})$ & $<0.36$ & $<0.01$ & 6.60 & $<0.59$ & $\mathrm{mg} / \mathrm{kg}$ & $\max .40(20 *)$ \\
\hline \multirow[t]{5}{*}{2} & Arsenic & $<0.08$ & 0.015 & $<0.01$ & 0.015 & $\mathrm{mg} / \mathrm{kg}$ & $\max .0 .1$ \\
\hline & Microbial contamination & & & & & & \\
\hline & Total Plate Figures (TPL) & $1.35 \times 10^{2}$ & $<3.5$ & $1.15 \times 10^{2}$ & $3.65 \times 10^{2}$ & colony $/ \mathrm{ml}$ & $\max .2 \times 10^{2}$ \\
\hline & Salmonella & negative & negative & negative & negative & $125 \mathrm{~g}$ & negative \\
\hline & Mold/Yeast & $6.1 \times 10^{1}$ & $<1$ & $1.3 \times 10^{2}$ & $<1$ & & $\max .50$ \\
\hline
\end{tabular}

*National Standardization Agency of Indonesia

\section{Discussion}

Metal Contamination: The metal content of arsenic (As) in the isotonic drink formula with the addition of gum arabic (biunik). The result of the analysis is still within the recommended threshold in SNI 01-4452-1998, namely Max. $0.1 \mathrm{mg} / \mathrm{kg}$. The concentration of As heavy metal contamination is still accepted in the four isotonic drink formulas with the addition of Arabic gum, making it safe for consumption. The mercury content in the four isotonic drink formulas with the addition of gum Arabic was still within the permissible threshold of $<0.0005 \mu \mathrm{g} / \mathrm{g}$ on examinations I and II. The maximum allowable limit of mercury/mercury $(\mathrm{Hg})$ contamination is Max. 0.03 $\mathrm{mg} / \mathrm{kg}$. The requirements for isotonic drinks according tothe Indonesian National Standard (INS) 01-44521998, the maximum limit of $\mathrm{Zn}$ metal contamination is max. $5.0 \mathrm{mg} / \mathrm{kg}$ The results of the analysis show that the average levels of $\mathrm{Zn}$ in the four isotonic drink formulas with the addition of Arabic gum are between $0.20 \mathrm{mg} / \mathrm{kg}$ to $1.11 \mathrm{mg} / \mathrm{kg}(<5.0 \mathrm{mg} / \mathrm{kg})$, meaning that the isotonic drink formula is safe for consumption. The maximum $\mathrm{B}$ of $\mathrm{Sn}$ metal contamination is max. $40(25.0 *) \mathrm{mg} / \mathrm{kg}$ in isotonic drinks according to INS 01-4452-1998. The analysis showed that the average $\mathrm{Sn}$ content in the four isotonic drink formulas with the addition of gum Arabic was $<40 \mathrm{mg} / \mathrm{kg}$, meaning that the isotonic drink formula was safe for consumption.

The requirement for isotonic drinks in SNI 01-44521998, the maximum limit of $\mathrm{Cu}$ metal contamination is $\max .2 .0 \mathrm{mg} / \mathrm{kg}$. The results of the analysis showed that the average levels of $\mathrm{Cu}$ in the four isotonic drink formulas with the addition of Arabic gum were between $0.21 \mathrm{mg} / \mathrm{kg}$ to $0.34 \mathrm{mg} / \mathrm{kg}(<2.0 \mathrm{mg} / \mathrm{kg})$, which means that the isotonic drink formula is safe for consumption. ${ }^{(10)}$

Lead $(\mathrm{Pb})$ is a metal that has received major attention in terms of health, because of its impact on a large number of people due to poisoning of food or air contaminated with $\mathrm{Pb}$ and has dangerous toxic properties. Naturally, lead can be found in the soil, odorless, and tasteless. ${ }^{(7)}$ The INS 01-4452-1998 set of heavy metal contamination limits for lead in isotonic drinks are consumed by humans is a maximum of 0.3 $\mathrm{mg} / \mathrm{kg}$. The average value of lead-heavy metal content in the four isotonic formulas with the addition of gum 
Arabic which has been analyzed is within the threshold so that it is safe for consumption. ${ }^{(8)}$

Microbial Contamination: The results of the analysis showed that the total average value of bacteria in the four isotonic drink formulas at examination I ( $>300 \times 10{ }^{5}$ Colonies/g) was much greater than the maximum value of TPC for bacteria (Total Plate Numbers $)$ required in SNI $\left(2 \times 10^{2}\right.$ Colonies/g). ${ }^{(10)}$ This means that this product is not safe for consumption. This data is the reason for the re-creation of the isotonic drink formula. Unlike the previous one, the formula is made and packaged using glass bottles. Before use, the bottles were sterilized at a temperature of $>100{ }^{\circ} \mathrm{C}$ for 15 minutes. Then, a microbiological analysis (examination II) was carried out at the Makassar Health Laboratory Center. Microbiology laboratory results showed that there was a drastic decrease in Bacterial TPC in all isotonic drink formulas. It is known that Bacterial TPC in F0, F1, and F2 is smaller than the maximum value of TPC for bacteria required in SNI for Indonesian isotonic drinks. This means that the formula is safe for consumption based on microbiological aspects. Bacteria TPC F3 (3.65 $\times 10^{2}$ colonies/g) has experienced a drastic decline te but still exceeded the quality standard isotonic drinks $\left(2 \times 10^{2}\right.$ colonies $\left./ g\right)$ if the review of aspects of microbiology.

This research is in line with the research of Rianti A, et al (2018) which showed that the results of TPC testing in green bean drink (GBD) samples showed that the contamination exceeds the maximum limit of microbial contamination. Meanwhile, the sample of soybean drink (SSD) and red bean drink (RBD) did not exceed the maximum limit of microbial contamination. The difference in the process of making SSD, RBD, and GBD samples lies in the type of material used. GBD samples were made with the addition of pandanus, while the SSD and RBD samples did not use these materials. ${ }^{(8)}$

Research on isotonic drink formulas with the addition of gum arabic in their packaging process is not good, so it can cause the risk of bacterial contamination. In making the first formula, drinks are packaged using plastic bottles that have been washed using soap and clean running water, then dried using dry tissue. No sterilization process is carried out on the bottles used. Unlike the second formula, the drinks are packaged using glass bottles that have been washed using soap and clean running water, then sterilized at a temperature $>$ $100^{\circ} \mathrm{C}$ for 15 minutes. The results of the microbiological quality analysis showed that the total fungi/yeast F1 and F3 had met the standards set in INS for Indonesian isotonic drinks. Microbiologically, the formula is safe for consumption. In contrast to F0 and F2, the amount of mold and yeast in the formula exceeds the set standard (maximum 50 Colonies $/ g$ ). The quality requirements contained in INS 01-4452-1998 require negative isotonic drinks Salmonella $S p$. The results showed that the isotonic drink formula with the addition of gum Arabic was not contaminated with Salmonella $s p .^{(1,11)}$

Ethic: This study has been approved by the Makassar Health Polytechnic Ethics Committee with the reference number:: 0087/KEPK-PTKMS/III/2020

Conflict of Interest: The researcher states there is no conflict of interest

Source of Funding: Self or other source

Funding from The Health Polytechnic of Makassar,

\section{Conclusion}

The results of the research show that theBiunik with the addition of gum arabic is safe from metal contamination in accordance with the SNI requirements for isotonic drinks. If assessed based on microbial contamination, F1 is an isotonic beverage formula with the addition of Arabic gum which is safe from microbial contamination.

\section{References}

1. Singh A, Chaudhary S SJ. Efficacy of pre exercise carbohydrate drink (Gatorade) on the recovery heart rate, blood lactate, and glucose levels in short-term intensive exercise. Serbian J Sport Sci [Internet]. 2015;5(1):2499-508.

2. Roomi MW, Roomi NW, Kalinovsky T, Niedzwiecki A, Rath M. In vivo and in vitro effect of a nutrient mixture on human hepatocarcinoma cell line SK-HEP-1. Exp Oncol. 2010;32(2):84-91.

3. Wiarto G. Nutrition Science in Sports . [Internet]. Vol. 1, Gosyen Publishing. Yogyakarta; 2013. 2018 p.

4. Jang LG, Choi G, Kim SW, Kim BY, Lee S, Park $\mathrm{H}$. The combination of sport and sport-specific diet is associated with characteristics of gut microbiota: An observational study. J Int Soc Sports Nutr. 2019;16(1):1-10.

5. Vogel RM, Joy JM, Falcone PH, Mosman MM, 
Kim MP, Moon JR. Safety of a dose-escalated pre-workout supplement in recreationally active females. J Int Soc Sports Nutr. 2015;12(1):1-6.

6. Hidayati N. Sports Nutrition Care [Internet]. Vol. 1, Rapha Publishing. 2015.

7. Control NA of D and F. Guidelines for Contamination Criteria in Ready-to-Serve Food and Home Industry Food. In: Director [Internet]. 2012.

8. Rianti, Angelina; Alvin Christopher DL \& WEK. Implementation of Food Safety and Sanitation in the Production of Healthy Drinks Jukajo Sukses Mulia MSMEs in Tangerang Regency. J Agrotechnology [Internet]. 2018;12(2):2499-508.
9. Andani, SA, \& Nurmasari W. The Effect of Giving Sweet Orange Juice (Citrus sinensis) on the VO2max Value of Football Athletes at the Fat Dony Training Camp (GDTC) Salatiga. Indones Nutr Journal [Internet]. 372(2):2499-508.

10. Agency NS. Indonesian National Standard (SNI) 01-4452-1998. In: New England Journal of Medicine [Internet]. 2018. p. 2499-508. 1

11. Prasetyowati, DA, Widowati, E., \& Nursiwi A. The Effect of the Addition of Arabic Gum on the Physicochemical and Sensory Characteristics of Pineapple (Ananas comosus L.Merr.) And Carrot (Daucus carota) Fruit Leather. J Agric Technol [Internet]. 2014;15(2). 